Pamiętnik Literacki 2017, 2, s. 143-166
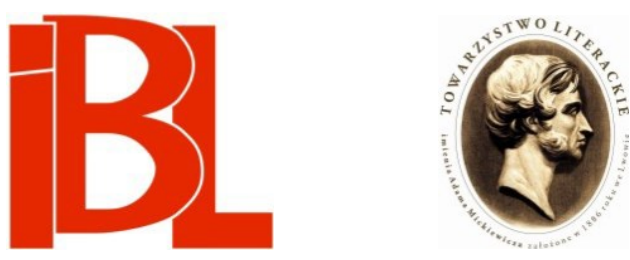

„Niepokój” - niemal zapomniany tom

poetycki Tadeusza Różewicza z 1947 roku

Piotr Pietrych 
PIOTR PIETRYCH Uniwersytet Jana Kochanowskiego, Kielce

\section{"NIEPOKÓJ" - NIEMAL ZAPOMNIANY TOM POETYCKI TADEUSZA RÓŻEWICZA Z 1947 ROKU}

Tytuł mojego szkicu wydawać się może czysta prowokacją, skoro chodzi o jedną z najważniejszych publikacji poetyckich w literaturze polskiej XX wieku. A jednak, mimo powszechnie uznanej rangi, Niepokój to książka słabo opisana i słabo funkcjonująca w dyskursie historycznoliterackim. W jakiejś mierze będę starał się to nadrobić, ale chcę również pokazać, że pierwszy tom poetycki Różewicza czytany w oryginalnym kształcie z 1947 roku pozwala w nowy sposób spojrzeć na początki jego twórczości.

Zacznę jednak od powodów swoistego zapoznania Niepokoju - dwa są zasadnicze.

Po pierwsze, zjawisko to wiąże się, cokolwiek paradoksalnie, $\mathrm{z}$ aprobatą, $\mathrm{z}$ jaką poezja Różewicza szybko się spotkała. Już w drugiej połowie lat pięćdziesiątych XX wieku zaledwie trzydziestoparoletni autor Ocalonego ogłoszony został „klasykiem” - przy okazji wydania, jak na klasyka przystało, Wierszy zebranych ${ }^{1}$. Rewersem sukcesu było kształtowanie się zestawu wierszy uznawanych za najważniejsze i najbardziej reprezentatywne, a także ich stereotypowych interpretacji. Właśnie w drugiej połowie lat pięćdziesiątych wczesną poezję Różewicza zaczęto czytać i cenić przede wszystkim jako naznaczone perspektywa „postkatastroficzną" dzieło "pogrobowca wojny” ${ }^{2}$ - co zarazem wiazało się ze spychaniem na margines innych jej wątków: widocznego zwłaszcza w utworach najwcześniejszych zafascynowania poetyką awangardową spod znaku Przybosia czy niebłahego, chociażby ze względów ilościowych, zaangażowania w socrealizm ${ }^{3}$.

W przypadku Niepokoju kształtowanie się schematów interpretacyjnych równało się sprowadzaniu obszernego i wewnętrznie zróżnicowanego zbioru wierszy do

$1 \quad$ L. Flaszen recenzję Wierszy zebranych Różewicza (1957) zatytułował po prostu: Laurka dla najmłodszego klasyka („Przegląd Kulturalny” 1958, nr 9, z 27 II - 5 III).

2 J. Błoń s ki, Szkic portretu poety współczesnego. W: Poeci i inni. Kraków 1956, s. 225, 239. Przywołuję określenia Błońskiego, ponieważ jego Szkic portretu to jeden z najważniejszych tekstów kodyfikujących lekturę poezji autora Ocalonego.

3 W latach 1950-1956 Różewicz co roku publikował nowy tom poetycki - z wyjątkiem r. 1953, w którym wydał jednak Wiersze wybrane. 
utworów przywołujących doświadczenie wojny, odczytywanych jako autobiograficzne świadectwo tego doświadczenia. Taki model lektury umacniał się w dekadach następnych -

Model lektury, który identyfikuje osobę autora z podmiotem mówiącym wiersza, narzucał się zwłaszcza w przypadku emblematycznego dla twórczości Różewicza wiersza Ocalony, który w odbiorze potocznym stał się swoistą synekdochalną reprezentacją całego jego poetyckiego dorobku i elementem najpowszechniejszego chyba deskryptywnego odpowiednika nazwiska autora ${ }^{4}$.

Tomasz Kunz wspomina o odbiorze potocznym - „klasyk” Różewicz trafił do programów szkolnych - ale traktowanie Ocalonego jako po prostu zapisu traumy wojennej autora i jako utworu „synekdochalnie” reprezentatywnego dla jego wczesnej poezji to interpretacja nierzadko akceptowana także przez badaczy literatury.

Powstanie selektywnego kanonu wierszy i ich stereotypowych odczytań to zapewne zjawisko nieuchronne, gdy poeta zdobywa szersza aprobatę oraz poczytność. W przypadku Różewicza jednak - i tu przechodzę do drugiego powodu swoistego zapoznania Niepokoju - był to proces współgrający z jego decyzjami edytorskimi: Różewicz nigdy nie przedrukował tego tomu w oryginalnym kształcie z 1947 roku. Przeciwnie, w zbiorowych wydaniach własnych wierszy zmieniał jego kompozycję i, co istotniejsze, zestaw zawartych w nim utworów, część skazując na zapomnienie, inne poddając redakcyjnym poprawkom, nierzadko daleko idącym. Po raz pierwszy zrewidował i przeredagował Niepokój właśnie w drugiej połowie lat pięćdziesiątych, w Poezjach zebranych; zmiany wtedy wprowadzone Andrzej Skrendo podsumowuje następująco: „1/5 wierszy została usunięta, połowa zaś pozostałych przerobiona $[\ldots]$...

Dla Skrendy, jednego z najważniejszych dziś komentatorów twórczości Różewicza, analiza edytorskich przemian Niepokoju to ostatecznie argument za tezą zasadniczą i postmodernistyczną z ducha: Różewicz nieustannie „"przepisuje" sam siebie”, a „niestabilność konstytuuje Różewiczowski idiom”6; to zaś, że „niestabilność” jest szczególnie wyraźna w przypadku Niepokoju, autor Przepisywania Różewicza skłonny jest uznać za gest „arbitralny”, „symboliczny”7. Można jednak nadać działaniom i wyborom Różewicza sens konkretny. Można i chyba trzeba, skoro uderzającą cechą recepcji Niepokoju pozostaje - antynomiczna wobec tekstowej „niestabilności” trwałość stereotypów interpretacyjnych z tym tomem związanych, wzmacnianych decyzjami poety „przepisującego” książkę z 1947 roku.

4 T. Ku n z, Strategie negatywne w poezji Tadeusza Różewicza. Od poetyki tekstu do poetyki lektury. Kraków 2005, s. 128.

5 A. Skr e nd o, Przepisywanie Różewicza. W: Przodem Różewicz. Warszawa 2012, s. 124. W oryginale Niepokój zawierał 54 wiersze, w wersji z 1957 r. - 40; liczba ta zwiększyła się nieco w kolejnych edycjach zbiorowych Różewicza (szczegółowe wyliczenie zmian zob. ibidem, s. 123-124).

$6 \quad$ Ibidem, s. 123.

7 Za interpretacja „symboliczną” przemawia, zdaniem S k r e ndy (ibidem, s. 133), to, że „przepisując" po raz kolejny Niepokój na potrzeby tomu poezji, który ukazał się w 2005 r. w Utworach zebranych, „Różewicz pisze swoją pierwszą książkę na nowo, żeby niejako domknać własną drogę poetycką". Jednak z oczywistych względów trudno taką interpretację zastosować do wcześniejszych niemal o pół wieku Wierszy zebranych z 1957 roku. 
Trwałość związanych z Niepokojem klisz interpretacyjnych nierzadko poświadczaja opinie czytelników profesjonalnych, paradoksalnie także te, w których problem stereotypów interpretacyjnych funkcjonujących w odbiorze wczesnej poezji Różewicza jest dostrzegany i werbalizowany, co zdaje się zapowiadać próbę krytycznej ich weryfikacji. Dwie takie nieudane próby chciałbym tu przywołać.

Czytelnika Niepokoju, jak i następnych tomów Różewicza, uderza ich wielkie zróżnicowanie wewnętrzne. Napotyka różne tematy, odmienne tonacje, przeciwstawne rozwiązania artystyczne. Nie dostrzega się naturalnie tego zróżnicowania przy redukcji ich do utworów „prawdziwie” Różewiczowskich. Przy takim postępowaniu poezja ta się homogenizuje, ujednolica, gdy naprawdę rządzą nią krańcowe przeciwieństwa. Gdy się w wierszach Różewicza szuka tylko charakterystycznych dla jego pokolenia głosów, nie słyszy się innych, niekiedy równie istotnych.

- konstatował już w latach siedemdziesiąych XX wieku Tadeusz Kłak ${ }^{8}$. Konstatacja to bardzo trafna i inspirująca, ale w tekstach Kłaka poświęconych początkom działalności literackiej Różewicza ${ }^{9}$ pozostaje swego rodzaju niespełnioną obietnicą.

Badacza bowiem nie interesuje krytyczny ogląd „homogenizacji”, która naznaczona jest recepcja Niepokoju i Czerwonej rękawiczki, lecz zupełnie inne zagadnienie: dlaczego te tomy poetyckie „o przełomowym znaczeniu” 10 nie od razu zdobyły powszechną aprobatę. Ostatecznie Kłak, zafascynowany twórczością Różewicza i pełen dla niej uznania, buduje opowieść o poezji autora Niepokoju jako osiagnnięciu tak przemyślanym i nowatorskim ${ }^{11}$, że nie byli mu w stanie sprostać nawet nietuzinkowi czytelnicy. Narracja ta ma ciemna stronę: wpływa na interpretację przywoływanych faktów, jest na swój sposób tendencyjna. Przykładem może być efektowne stwierdzenie z początku Kontekstów „Niepokoju”:

O Najcichszym sztandarze Adama Włodka pisano więcej niż o Niepokoju, pierwszemu poświęcili swe pióra krytycy i pisarze uznani (Kazimierz Czachowski, Kazimierz Wyka, Jerzy Zagórski), o wczesnych książkach Różewicza pisali raczej rówieśnicy, jeśli nie liczyć okazjonalnych wypowiedzi Leopolda Staffa i Juliana Przybosia ${ }^{12}$.

Perswazyjna moc tego stwierdzenia zawartego w rozprawie, w której tytule podkreśla się wagę kontekstów, wynika właśnie $\mathrm{z}$ braku precyzji w zarysowaniu

8 W roku 1977 T. Kłak opublikował rocznicowy tekst XXX lat „Niepokoju” („Poezja” 1977, nr 11), który następnie rozszerzył i pod tytułem Wokół „Niepokoju” Tadeusza Różewicza zamieścił w swojej książce Reporter róż. Studia i szkice literackie (Katowice 1978). Cyt. za przedrukiem w późniejszej pracy T. Kła ka, Spojrzenia. Szkice o poezji Tadeusza Różewicza (Katowice 1999, s. 91), w której szkic ten ukazał się w identycznym kształcie, poza, niezbyt fortunną, zmianą tytułu na: Konteksty „Niepokoju”.

9 W Spojrzeniach obok Kontekstów „Niepokoju” znalazł się obszerny, napisany w latach dziewięćdziesiątych, tekst T. Kła ka Wejście Różewicza.

10 Kła k, Spojrzenia, s. 81.

11 W Kontekstach „Niepokoju” to ważna supozycja, która została zwerbalizowana w Wejściu Różewicza, gdzie Kłak (Spojrzenia, s. 35) wprost stwierdza, że młody poeta „zamierzał iść konsekwentnie obrana przez siebie drogą" i konsekwentnie „budował fundamenty całej swojej liryki”, dokonując tym samym literackiego przełomu - „bowiem liryka ta powodowała prawdziwy przełom w poezji polskiej, i nie tylko w niej, otwierała nową epokę poetycką". 
tychże. W niemałym stopniu zainteresowanie dla tomiku Włodka wiązało się z tym, że ukazał się on w 1945 roku i był nie tylko jedna z pierwszych publikacji poetów wówczas najmłodszych, ale w ogóle jedną z pierwszych po wojnie publikacji poetyckich (nb. Wyka odniósł się do wierszy Włodka zdecydowanie krytycznie ${ }^{13}$ ); Niepokój ogłoszony został półtora roku później, co może się wydawać niezbyt dużym dystansem czasowym, lecz wtedy oznaczało to już zupełnie inną sytuację wydawniczą i zdecydowanie bogatsze w wydarzenia życie literackie. Jednak przede wszystkim trudno zgodzić się z sugestią, że wyjątkowość Różewicza pozostawała niedostrzeżona, skoro jeszcze przed ukazaniem się Niepokoju, gdy jego wiersze znano tylko z publikacji prasowych, kształtowała się opinia, że jest on jedynym młodym poeta, „przed którym zdaje się być otwarta droga wybitnych osiagnięć" ${ }^{14}$, opinia podzielana publicznie także przez Wykę ${ }^{15}$.

Wątpliwości budzą nie tylko szczegółowe stwierdzenia, ale i budowane przez Kłaka uogólnienia. Tezie, że młodzi pisarze i poeci byli jakoś marginalizowani w powojennym życiu literackim ${ }^{16}$, przeciwstawić można dokładnie odwrotną i, jak się wydaje, lepiej uargumentowaną tezę Zbigniewa Jarosińskiego, który podkreślał, że po 1945 roku twórcy z pokolenia 1920 niezwykle szybko stali się ważnymi postaciami w polskiej literaturze ${ }^{17}$.

Ale największą wadą narracji Kłaka jest zaniechanie. Choć badacz dostrzega w tomie poetyckim Różewicza „krańcowe przeciwieństwa”, nie zajmuje się problemem, w jakim stopniu ich występowanie wpłynęło na odbiór Niepokoju, czy jego „przełomowość” była w ogóle dostrzegalna, skoro pojawiała się uwikłana w owe „przeciwieństwa”. Pytania te prowadzą do jeszcze jednego, bardziej zasadniczego: w jakim stopniu „homogenizacja” wczesnej poezji Różewicza, jej „redukcja [...] do utworów "prawdziwie« Różewiczowskich", tej poezji jednak dobrze się przysłużyła, wydobywając, a może wręcz współtworząc jej przełomowość?

3

Drugi znaczący tekst próbujący podważyć spetryfikowane sposoby lektury Niepokoju, który chcę tu przywołać, to szkic Krzysztofa Kłosińskiego zawarty w jego ksiażce Poezja żalu i zatytułowany po prostu „Niepokój” Tadeusza Różewicza18. Kłosiński źródło stereotypów w odczytywaniu wczesnych wierszy Różewicza widzi

K. Wy k a, Wiersze Włodka. „Odrodzenie” 1945, nr 40, z 2 IX.

Jaszcz [J. A. Szczepański], Punkty kontrolne. „Dziennik Literacki” 1947, nr 1, z 7-14 III. Kłak zna ten artykuł i przywołuje sąd Jaszcza - w innym miejscu swojej rozprawy (Spojrzenia, s. 114).

Zob. Kto jest realistą? Rozmowa z K. Wyka. „Dziennik Literacki” 1947, nr 10, z 9-15 V: „Wiersze zebrane w Niepokoju Różewicza bardziej mnie przejęły w tomie niż rozproszone po czasopismach. Jedyny to autentycznie młody głos po tych ciemnych czasach wojennych”. Prywatnie Wyka był w ocenie Niepokoju bardziej wstrzemięźliwy, o czym będzie jeszcze mowa, ale nieodmiennie wyróżniał Różewicza na tle innych młodych poetów.

Kła k, Spojrzenia, s. 81-82.

Z. J a r o sińs ki, Rok 1945 jako cezura literacka. W zb.: Stare i nowe $w$ literaturze najnowszej. Z problemów literatury polskiej po 1945 roku. Red. L. W iśn i ew s ka. Bydgoszcz 1996, s. 19.

K. Kło sińs ki, „Niepokój” Tadeusza Różewicza. W: Poezja żalu. Katowice 2001. Pierwsza, naj- 
w marginalizowaniu czy wręcz pomijaniu ich literackości. Traktowanie Ocalonego jako „das Literarische Kunstwerk” - Kłosiński dość nieoczekiwanie robi tu aluzję do Ingardena - „zostało zaraz po wojnie uniemożliwione”, ponieważ doszło do „szczególnej fiksacji sensów”, wynikającej z narzucenia „kagańca kontekstu historycznego" ${ }^{19}$. Autor Poezji żalu przywołuje Edwarda Balcerzana, który już w latach siedemdziesiątych pisał:

W 1947 roku, kiedy ukazał się Niepokój Tadeusza Różewicza, trudno by oczekiwać recepcji preferującej fikcyjność opowiedzianych w tym wierszu wydarzeń. Bez wątpienia, Ocalony Różewicza jest dziełem sztuki i pełna interpretacja musi ten fakt uwzględnić. [...] Ale dla czytelnika z 1947 roku Ocalony był przede wszystkim wyznaniem autora (nie podmiotu fikcyjnego), znakiem zwróconym ku niedawnej przeszłości narodu (a nie ku przestrzeni wewnątrztekstowej), jak i inne, wspomnieniowe, publicystyczne itp. dokumenty okropności wojny. [...] Jego poetyckość miała sens instrumentalny: jak $\mathrm{w}$ folklorze in statu nascendi ${ }^{20}$.

Utożsamiając „fikcyjność”, o której pisał Balcerzan, z literackością, Kłosiński zwraca uwage na jej istnienie we wczesnych wierszach Różewicza, pokazuje ich uwikłanie w procedury metaforyzacyjne i relacje intertekstualne.

Interpretacje Kłosińskiego, erudycyjne i wyrafinowane, oparte na odwołaniach do autorytetów humanistyki przełomu wieków (Derrida, de Man, Lacan), mają jednak zaskakująco słabe fundamenty filologiczne. Jedna z konsekwencji „przepisywania Różewicza” jest to, że, jak zauważył Skrendo przy innej okazji, „nie wszyscy, którzy spierają się o jego [tj. Niepokoju] rolę w historii polskiej poezji, sięgaja po pierwodruk" ${ }^{21}$ - i Kłosiński może być właśnie przykładem takiego badacza. Tylko formalnie bowiem zajmuje się tomem z 1947 roku, de facto zajmując się jego „przepisaną" przez poetę wersją: konsekwentnie przywołuje wiersze z Niepokoju za wydaniem zbiorowym poezji Różewicza z 1988 roku.

Nie mniej istotny jest inny anachronizm pojawiający się w rozważaniach Kłosińskiego. Naruszenie „normalności” ${ }^{22}$ w traktowaniu wierszy Różewicza jako dzieł literackich wiąże badacz z dominującym wśród czytelników przekonaniem o „dokumentalnym" charakterze tych utworów. Lecz choć w cytowanym tu, a także przez

obszerniejsza część tego tekstu, poświęcona wierszowi Róża, ukazała się najpierw w „Pamiętniku Literackim" (1999, z. 1) pt. Imię róży i bywa często przywoływana za pierwodrukiem.

Kło s ińs ki, „Niepokój” Tadeusza Różewicza, s. 154-155.

E. B a l c e rz a n, Interpretacja jako „próba całości” (na przykładzie polskiej liryki powojennej). W zb.: Zagadnienia literaturoznawczej interpretacji. Studia. Red. J. Sła w iń s ki, J. Świ ę ch. Wrocław 1979, s. 87. Zob. też E. B a lc e r z a n, Poezja polska w latach 1939-1965. Cz. 1: Strategie liryczne. Warszawa 1982, s. 24-25. Łatwiej w tym przypadku zacytować bezpośrednio Balcerzana niż Kłosińskiego, ponieważ jego uwagi uwikłane zostały w referowanie i komentowanie fragmentu Interpretacji jako „próby całości”, z którego pochodzi ten cytat. Referowanie to zresztą w pełni aprobatywne, co $\mathrm{z}$ dwóch powodów warto podkreślić. Po pierwsze: Balcerzan traktuje Ocalonego jako oczywistą synekdochę wczesnej poezji Różewicza i u Kłosińskiego brak sygnałów dystansu wobec tego zabiegu. Po drugie: zaskakuje u autora piszącego pod koniec XX w. i oczytanego w literaturze postmodernistycznej aprobata dla stanowiącej fundament sformułowań strukturalisty (w latach siedemdziesiątych XX w.) Balcerzana wyraźnie modernistycznej opozycji „dzieła sztuki” i „dokumentu"; być może, wątpliwości, jakie pociąga za sobą odwołanie się współcześnie do tej opozycji, Kłosiński stara się zamaskować Ingardenowską peryfrazą.

A. Skrend o, Twórczość Tadeusza Różewicza w zarysie. W: Przodem Różewicz, s. 14.

Kło s iń s ki, „Niepokój” Tadeusza Różewicza, s. 155. 
Kłosińskiego, fragmencie artykułu Balcerzana mowa o „czytelniku z 1947 roku”, autor Poezji żalu pokazuje istnienie tego przekonania nie na podstawie pierwszych opinii o Niepokoju, ale - tekstów późniejszych, poczynając od ważnych ujęć Błońskiego i Wyki z lat pięćdziesiątych. Najwyraźniej źródłem wyobrażeń Kłosińskiego (i Balcerzana) na temat „czytelnika z 1947 roku” sa, wbrew tej peryfrazie, sposoby interpretacji poezji Różewicza, które zaczęły się kształtować w dekadzie następnej i przez badaczy zostały ekstrapolowane na lata czterdzieste.

Anachronizmy w rozważaniach Kłosińskiego powodują, że rewersem niechęci do „kagańca kontekstu historycznego” okazuje się w nich stereotypowe postrzeganie tego kontekstu. Rozumowanie autora Poezji żalu warto więc odwrócić: to nie kontekst historyczny jest „kagańcem [...], któremu zawdzięczamy ową szczególną fiksację sensów w odczytaniu takich wierszy, jak Ocalony”"23, ale przeciwnie: „fiksacja sensów" wiąże się ze schematycznym postrzeganiem owego kontekstu i jego oddziaływania na poezję Różewicza.

Na zakończenie uwag wstępnych warto przywołać recenzje Niepokoju, zasadnicze źródło wiedzy na temat „czytelnika z 1947 roku”. Nie potwierdzają one przekonania, które zyskało potem status oczywistości, że tom młodego poety czytano jako „dokument okropności wojny”, a jego „poetyckość” miała dla pierwszych czytelników jedynie „sens instrumentalny”. Było właściwie dokładnie odwrotnie: Niepokój czytano przede wszystkim - użyjmy jeszcze jednego określenia Balcerzana - w „przestrzeni wewnątrztekstowej”, jako tom poetycki i to właśnie jego „poetyckość” głównie interesowała recenzentów.

Wyrazistym tego przykładem może być omówienie Niepokoju opublikowane przez Stanisława Lema. Odnotował on tematykę wierszy, wskazując na ich „wydźwięk” - „Wydźwięk poezji Różewicza jest pesymistyczny: przeżycia okupacji rozbiły mu hierarchię pojęć etycznych i wiare" - ale zrobił to dosłownie w jednym, tym właśnie, zdaniu. Natomiast nieliczne w recenzji obszerniejsze cytaty, choć pochodzą z utworów wojnę przywołujących, posłużyły Lemowi do rozważania kwestii warsztatowych: Dolę, mówiąca o zabitym partyzancie, zacytował, chcąc unaocznić czytelnikowi i pochwalić obrazowanie oparte na „niedocenianej prostocie”, z kolei fragment wiersza $Z$ domu mojego, którego bohater stracił w wyniku wojennego kataklizmu dom rodzinny i najbliższych, został przywołany, aby pokazać metaforykę Różewicza, to, że młody poeta umiał trafnie wykorzystać „metaforę na służbie kształtu lirycznego"24.

Dla recenzentów ważnym „wewnątrztekstowym” zagadnieniem była kwestia inspiracji literackich widocznych w wierszach Niepokoju. Jako oczywiste odnotowywali oni związki z poezją Przybosia, ale wskazywali też na inne zapożyczenia i pokrewieństwa, w tym - co warto podkreślić, bo potem ten trop z interpretacji

24 S. Le m, Wiersze Różewicza. „Tygodnik Powszechny” 1947, nr 45, z 9 XI, s. 6. Jako ciekawostkę warto odnotować, że późniejszy wybitny prozaik recenzję Niepokoju napisał z pozycji... młodego poety katolickiego. 
poezji Różewicza zniknie - na źródła literackie dykcji sprozaizowanej, która po latach stanie się synonimem poezji „Różewiczowskiej”: w użyciu takiej dykcji recenzenci dość zgodnie, różnie zresztą to oceniając, widzieli wpływ poezji francuskiej, Apollinaire’a i surrealistów, a także okupacyjnej poezji Miłosza. Ponownie posłużę się tu recenzją Lema: w „prostocie” Doli dostrzegł on „coś z Miłoszowskich skrótów lirycznych” i podobieństwo do „oszczędnej w wypowiedzi przedwojennej poezji francuskiej" 25 .

Natomiast zdecydowanie mniejsze zainteresowanie budził w recenzentach Niepokoju zapis doświadczenia wojennego; jeden $\mathrm{z}$ nich - co z punktu widzenia późniejszych wyobrażeń o „czytelniku z 1947 roku” wydawać się może niezrozumiałą osobliwością - w ogóle pominął wojenną tematykę wierszy Różewicza milczeniem² ${ }^{26}$. Był to przypadek skrajny, ale wyjaskrawiający tendencję dominującą w omówieniach książki młodego poety.

Przywołać tu wszakże trzeba jeszcze jedną recenzję, która ukazała się w „Odrodzeniu” i której autorem był Jerzy Zawieyski. To tekst ważny zarówno ze względu na miejsce publikacji, jak i ze względu na wysoką rangę autora w ówczesnym życiu literackim, a także dlatego, że podkreśla znaczenie tematu wojny w wierszach Różewicza, co więcej, do pewnego stopnia antycypuje późniejsze sposoby ich interpretacji. Ale nawet Zawieyski, który uznanie dla utworów z Niepokoju wyrażał przez przypisywanie im „realistyczności” - mówił o ich „realizmie poetyckim” czy po

Ibidem. Dostrzeganie intertekstualnego aspektu prozaizacji, która pojawiła się w wierszach Różewicza, wpływu, a co najmniej „pokrewieństwa” między nimi a „poetyką uproszczonego nadrealizmu” było dla krytyków w drugiej połowie lat czterdziestych czymś oczywistym. J. Błońs ki (Poezja Różewicza. „Twórczość” 1949, z. 7, s. 113), którego wyrażenia z recenzji Czerwonej rękawiczki tu przywołuję, ukonkretnia to skojarzenie wskazując „pokrewieństwa” między Ocalonym a wierszem P. Éluarda Gabriel Péri. Jednocześnie warto w tym kontekście zauważyć, że utrwalanie się sposobu lektury wczesnej poezji Różewicza jako przede wszystkim dzieła „pogrobowca wojny”, do czego Błoński walnie się przyczynił Szkicem portretu poety współczesnego w połowie dekady następnej, oznaczało zacieranie intertekstualnych uwikłań tej poezji. Proces to dobrze widoczny właśnie w Szkicu portretu. Co prawda, ze wskazania na „pokrewieństwo” ani z zestawienia Ocalonego z Gabrielem Péri Błońs k i (Szkic portretu poety współczesnego, s. 239) w tym tekście nie rezygnuje, ale podkreśla, że ma na myśli jedynie „pozorną wycieczkę wpływologiczna”, i mówi zdecydowanie: „Powtarzam: nie chodzi o wpływ, bo go nie ma, ale o analogie”. Jednak stanowczość Błońs kiego nie wydaje się uzasadniona, wątpliwy jest bowiem jej fundament, twierdzenie, że awangardowych poetów francuskich „Różewicz po prostu nie znał - bo nie znał ich języka, jak chętnie przyznaje" (ibidem, s. 237). W drugiej połowie lat czterdziestych ukazała się głośna wtedy Antologia współczesnej poezji francuskiej opracowana przez A. W aży ka (Błońs ki przywołuje ją zresztą w przypisie, zob. ibidem, s. 273), ukazała się, co prawda, w roku wydania przez Różewicza Niepokoju, ale przekłady w niej zawarte były wcześniej publikowane w prasie literackiej i Różewicz kilka miesięcy przed wydrukowaniem Ocalonego w „Odrodzeniu” mógł czytać Gabriela Péri P. Éluarda (Wiersze. „Kuźnica” 1945, nr 9, z 28 X), wpływu nie da się więc wykluczyć. To prawdopodobna hipoteza, w dodatku jest rzeczą pewną, że Różewicz w pierwszych latach działalności literackiej wiersz Éluarda poznał i najwyraźniej go cenił, skoro sam napisał utwór poświęcony pamięci francuskiego komunisty, zamordowanego w czasie wojny przez hitlerowców, utwór, który także zatytułował Gabiel Péri (pierwodruk, w dziesiąta rocznicę śmierci Périego: „Twórczość” 1951, z. 10; przedruk w: T. Różew i c z, Wiersze i obrazy. Warszawa 1952) i w którym cytuje fragmenty wiersza Éluarda w przekładzie J. Kotta, opublikowanym po raz pierwszy w „Kuźnicy” jesienią 1945 (a następnie zamieszczonym w antologii Ważyka). 
prostu o „realizmie” - i stwierdzał, że „Wiersze, wyrosłe z wojny, są obnażeniem faktów”, że wyrażaja „surowa prawdę”, nie traktował ich ostatecznie jako prostej ekspresji „faktów” i „prawdy”. Widział w nich bowiem nie tyle „dokument”, ile jednak - i przede wszystkim - osiagnięcie artystyczne, pisał o „wrażeniu poetyckim dużej miary” oraz o „Zwycięstwie poety” 27 .

Opublikowany wiosną 1947 Niepokój zawierał 54 utwory i były to, jak głosiła zamieszczona na końcu tomu adnotacja, „Wiersze z lat 1945-1946” (N 71 28). W zdecydowanej większości - tylko siedmiu z nich to nie dotyczy - utwory te były wcześniej drukowane w pismach literackich, w których nazwisko Różewicza pojawiało się od września 1945, kiedy zadebiutował na łamach „Odrodzenia”. Niepokój miał zarazem charakter tomu wierszy zebranych z okresu, o którym mowa w adnotacji: Różewicz włączył do niego właściwie wszystkie opublikowane wcześniej w prasie utwory poetyckie (poza satyrycznymi, drukowanymi głównie w „Szpilkach” i w śląskim „Kocyndrze”29). Wyjątki są nieliczne i jedynie potwierdzają regułę: do książki nie wszedł wiersz Do żołnierza-tułacza, opublikowany w 1946 roku we wrześniowym numerze tygodnika „Wieś”, zapewne w związku z rocznica wybuchy wojny, bo powstał w okresie okupacji, nosił datę „1943 r.” ${ }^{30}$; w Niepokoju nie znalazła się Elegia na powrót umarłych poetów, manifest niechęci do poezji tradycyjnej, w tym przypadku zadecydował zapewne publicystyczno-satyryczny charakter utworu ${ }^{31}$; Różewicz do Niepokoju nie włączył również Katastrofy, mówiącej o tragicznym wypadku kolejowym, który to wiersz po ukazaniu się w „Odrodzeniu” sprowokował w prasie rozważania o „katastrofie w poezji”, bulwersował bowiem dosadnością obrazowania, w tym erotycznego ${ }^{32}$.

Pomijając te wyjątki, Niepokój zbierał wszystkie opublikowane wcześniej nie-

J. Zawi ey s ki, Poezja niepokoju. „Odrodzenie” 1947, nr 42, z 19 X, s. 5.

W ten sposób lokalizuję cytaty z tomu: T. Ró że wi c z, Niepokój. Kraków 1947. Liczba po skrócie wskazuje stronicę.

Część z nich poeta włączył do tomu Uśmiechy, wydanego dopiero w r. 1955, warto więc pamiętać, że powstawały one równolegle $z$,poważnymi” wierszami z Niepokoju, że, mówiąc inaczej, autor Ocalonego pisywał jednocześnie utwory satyryczne i humorystyczne.

T. Ró ż e w i c z, Do żołnierza-tułacza. „Wieś” 1946, nr 34/35, z 1-7 IX. W późniejszych przedrukach tego utworu poeta zaznaczał, że jego współautorem był Janusz Róże wi c z - zob. Nasz starszy brat. Oprac. T. Różewicz. Wrocław 1992, s. 5.

T. Róż e wi c z, Elegia na powrót umarłych poetów. „Pokolenie” 1946, nr 1.

T. Różew i cz, Katastrofa. „Odrodzenie” 1946, nr 43, z 27 X. Zob. Wła d., Katastrofa w poezji. „Rzeczpospolita” 1946, nr 298, z 29 X, s. 6. Autor felietonu domyśla się, że gdy Różewicz pisze o „uśmiechniętych zadach kobiet / na kartofliskach” obserwowanych przez jednego z pasażerów pociągu, chodzi o oddanie „rozpalonej wyobraźni chłopca”, tym niemniej uznaje to wyrażenie za dowód upadku poezji, podobnie jak opis kłopotów bohatera $z$ artykulacją („Pijany, słowa ciągnął / z ust jak ślimaki / oślinione i śliskie / przyklejał do szyby”); felieton zamieszczony w ogólnopolskim dzienniku przedrukowywany był w prasie lokalnej. Warto przy okazji odnotować, że już w październiku 1946 Różewicz, co „Wład.” konstatuje oczywiście z dystansem, zaliczany był „do niecodziennych zjawisk w szkółce poetyckiej Przybosia”. 
satyryczne utwory Różewicza $z$ lat $1945-1946^{33}$, i to zbierał o tyle dosłownie, że autor przedrukował je w książce bez wprowadzania żadnych znaczących zmian ${ }^{34}$. Obfitość prasowych pierwodruków wierszy tworzących Niepokój jest faktem wartym uwagi i wykorzystania. Choć oczywiście nie można traktować dat pierwodruków jako danych rozstrzygających kwestię czasu powstania poszczególnych utworów, uwzględnienie tych dat pozwala nałożyć na zawartość książki Różewicza pewien porządek chronologiczny (w tomie kolejność pierwodruków nie została zachowana) i w efekcie wydobyć $z$ niej interesujące informacje.

Taki zabieg ujawnia przede wszystkim wyraźną ewolucję: w ciagu mniej więcej półtora roku, od września 1945 do wczesnej wiosny 1947, kiedy w prasie literackiej drukowane są wiersze, które wejdą już do Czerwonej rękawiczki, Różewicz przechodzi od wzorowania się na awangardowej poezji Przybosia do poetyki zdecydowanie bardziej ascetycznej, ograniczając czy wręcz rugując metafory na poziomie zdania

Bez przebadania archiwum poety trudno wypowiadać się o wierszach, które wtedy zapewne powstały, ale nie zostały zakwalifikowane przez autora, bądź jego ówczesnego mentora Przybosia, do druku (zob. interesujący list Przybosia do Różewicza z września 1945, w którym pojawia się kilka tytułów wierszy młodego poety, nie zawsze dających się dziś zidentyfikować - T. Różewicz, Margines, ale... Wrocław 2010, s. 139). Na podstawie dostępnych materiałów można wymienić jeden taki przykład, bardzo zresztą interesujący: wiersz O maleństwie piosenka. Z. M aj c hrows ki (Różewicz. Wrocław 2002, s. 86) opublikował zdjęcie maszynopisu tego utworu, datowanego „kwiecień 1945 r.”, z poprawkami Przybosia, dającymi wyobrażenie o wskazówkach, jakie mistrz kierował do młodego ucznia. Ale nie mniej interesujące jest to, że wiersz opowiadający o groźnym dla wroga, lecz czułym dla niemowlęcia żołnierzu - „radzieckim / płowym / lwie”, włączony przez Róż e w i c za do tomu Czas który idzie, wydanego w r. 1951, kiedy utwór ten mógł sprawiać wrażenie sielankowej idealizacji rzeczywistości końca wojny dokonanej zgodnie z wymogami socrealizmu - powstał jednak w r. 1945, a tym samym zdumiewająco uproszczoną i sentymentalną wizję radzieckich „ „wów” w całości zapisać trzeba na konto autora.

W przypadku dwu wierszy: Martwy owoc i $Z$ domu mojego, zmiana polegała na nadaniu im tytułu - w pierwodruku tytułu one nie miały (zob. „Odrodzenie” 1946, nr 33, z 18 VIII). Jedynym w znaczącym stopniu zmienionym utworem w Niepokoju był Przemarsz przez wieś, pozbawiony w edycji książkowej w stosunku do pierwodruku („Pokolenie” 1946, nr 3, z 1 X, s. 5) siedmiu końcowych wersów:

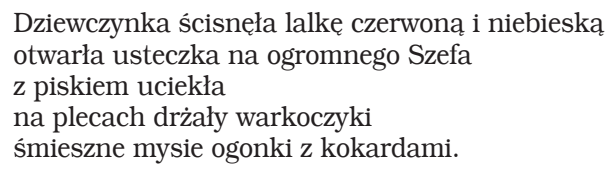

Kiedy odeszli rozchyliły się na szybach

białe kwiaty pod tchnieniem gorących warg. [w. 27-34]

Zmiana może być odczytana jako istotna: $w$ jej wyniku wiersz nabiera innego charakteru, nie jest już tylko rodzajową scenka, a to, co owe końcowe wersy poprzedzało i było w pierwodruku tylko poetyckim opisem obrazka wiszącego na ścianie chłopskiej chaty, stając się zakończeniem, jednocześnie wprowadza wzniosłą sugestię błogosławieństwa dla odwiedzających chatę partyzantów:

na obrazach wschodziły aureole

i biała Gołębica migotała piórami nad Synem. [w. 24-26]

Ale niewykluczone, że jest to zmiana przypadkowa: siedem wersów zamykających Przemarsz w niewielkim rozmiarami Niepokoju powinno się znaleźć na następnej stronicy książki i, być może, „wypadło" przy łamaniu tekstu (zob. N 43-44). 
i zbliżając styl swoich utworów do języka potocznego. Jednocześnie chronologiczna perspektywa pierwodruków pozwala dostrzec, że proces uwalniania się spod wpływu Przybosia miał w przypadku autora Niepokoju przebieg złożony i meandryczny, nie było nagłego zwrotu czy zerwania. Tak więc np. Śmierć podchorążego, w której Różewicz sięga po Przybosiowskie metafory, aby pisać o doświadczeniu wojennym (będzie jeszcze o tym utworze mowa), został opublikowany po Ocalonym, funkcjonującym potem jako sztandarowy przykład tematyki i poetyki „Różewiczowskiej”35.

Różewicz tuż po wojnie rozpoczynał od fascynacji awangardą w wersji Przybosia, aby następnie przejść szybką i radykalną ewolucję od metaforyzacji do prozaizacji swoich wierszy. Na takim poziomie uogólnienia są to fakty w pracach Różewiczowi poświęconych odnotowywane; stosunkowo dużo pisano o wpływie Przybosia na najwcześniejsze wiersze autora Niepokoju ${ }^{36}$. Ale warto do tej kwestii wrócić, ponieważ i ten wpływ, i związana $z$ wyzwalaniem się spod niego ewolucja twórczości poetyckiej Różewicza traktowane bywają zazwyczaj jako zjawiska marginalne, rozgrywające się gdzieś na obrzeżach tomu z 1947 roku. Tymczasem tom ten, chociażby ze względu na swój charakter „wierszy zebranych”, zapisywał zarówno ów wpływ, jak i ową ewolucję w sposób wyraźny, co miało istotne konsekwencje dla jego odbioru.

A był to na początku, tzn. w roku 1945, wpływ bardzo silny. Już w kwietniu tego roku Różewicz opublikował manifest Rekwizyty i duch, w którym objawił się jako zwolennik poezji rozwijającej idee Awangardy Krakowskiej. Manifest otwierało gromkie stwierdzenie: „Poeta, jako twórca rzeczy nowych, jest nowatorem i rewolucjonista” ${ }^{37}$, całość zaś niewielkiego tekstu brzmiała ,jak telegraficzne streszczenie programu poetyckiego Tadeusza Peipera $z$ jego Nowych ust"38. Warto też zauważyć, że choć w kwietniu 1945 działania wojenne jeszcze trwały, a Różewicz miał za sobą wszystkie przeżycia, które złożyły się na jego osobiste doświadczenie wojny (w tym te najistotniejsze - udział w partyzantce, śmierć brata Janusza), w manifeście brak do niej odniesień, co sugeruje, że, zdaniem autora, nie miała ona wpływu na zasady tworzenia poezji. To oczywiście tylko sugestia Rekwizytów i ducha, trudno powiedzieć, w jakiej mierze świadomie wprowadzona, choć warta odnotowania, zwłaszcza w kontekście późniejszych wypowiedzi Różewicza na ten temat; ale, rzecz jasna, manifest miał przede wszystkim poświadczać aspiracje twórcze autora. Jest też w jakimś stopniu naturalne i zrozumiałe, że choć początkujący poeta pisze o „rzeczach nowych”, „nowatorstwo” oznaczało w jego przypadku wybór mistrza literackiego i próby jego naśladowania; a to, że Różewicz wybrał Przybosia, nie było czymś niezwykłym ani oryginalnym, jak stwierdza Grzegorz

T. Różewi cz: Ocalony. „Odrodzenie” 1946, nr 15, z 14 IV; Śmierć podchorażego. Jw., nr 21, z 26 V. Jeszcze później, prawie pół roku po pierwodruku Ocalonego, ukazał się wiersz Żywi umierali („Pokolenie” 1946, nr 3, z 1 X), w którym Różewicz próbuje metaforycznie przedstawić zagładę Żydów.

36 Zob. A. Skrendo, Przyboś i Różewicz. Paralela. W: Poezja modernizmu. Interpretacje. Kraków 2005; autor daje tu także przegląd wcześniejszych opinii na temat relacji między oboma poetami. Tekst Różewicza ukazał się 14 IV 1945 w pierwszym numerze „Przemian”, dodatku Związku Zawodowego Literatów w Częstochowie do dziennika „Głos Narodu” (nr 50). Cyt. za: L. M. B arte ls ki, W kregu bliskich. Szkice do portretów. Kraków 1967, s. 178. 
Wołowiec: „Dla większości debiutujących tuż po wojnie poetów był Przyboś prawdziwym Mistrzem"39.

Fascynację Przybosiem świetnie widać w „najwcześniejszych” (gdy spojrzeć na zawartość Niepokoju z perspektywy chronologicznej) wierszach Różewicza, opublikowanych jesienia 1945. Bardzo chłodno ocenił je Karol Wiktor Zawodziński w swoim Rzucie oka na literature polska 1945 roku:

Tylko z podpisu Różewicza w „Odrodzeniu” odróżniamy jego pierwociny od wzoru [tj. Przybosia]; tenże prozą opowiada zupełnie dorzecznie ${ }^{40}$, ale w wierszu jest zahipnotyzowany manierą mistrza. Tak łatwo zafundować sobie satysfakcję osiagnięcia celu: anch'io son' poeta! ${ }^{11}$

Zawodziński nie lubił poezji awangardowej i to, że Różewicz wzorował się na Przybosiu, niewątpliwie z góry źle nastawiało krytyka do początkującego poety. Ale najciekawsze w opinii Zawodzińskiego jest to, że jakkolwiek w pierwszym momencie wydawać się ona może przede wszystkim objawem idiosynkrazji ${ }^{42}$, w podsumowaniu dorobku literatury polskiej za rok 1945 była po prostu uzasadniona. W tymże roku Różewicz opublikował w „Odrodzeniu” sześć wierszy wyraźnie odwołujących się do wzorca poezji awangardowej, w jednym $\mathrm{z}$ nich - Na widnokręgu-dając wręcz pastisz Przybosia, pod względem nie tylko poetyki, ale i wyboru bohatera, zupełnie w twórczości Różewicza wyjątkowego: jest nim rolnik-siewca.

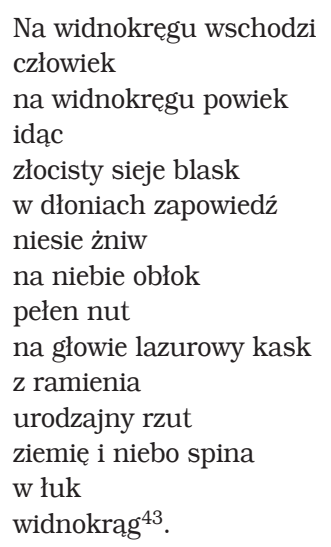

Być może, wyrazistość patronatu Przybosia nad pierwszymi drukowanymi wierszami Różewicza wynikała w jakiejś mierze z tego, że autor Miejsca na Ziemi był szefem działu poezji w „Odrodzeniu” i młody poeta mniej lub bardziej świadomie wybierał i przesyłał do redakcji takie teksty, które mogły liczyć na jego przychylność.

G. W oł ow i e c, Nowocześni w PRL. Przyboś i Sandauer. Wrocław 1999, s. 45.

Jesienią 1945 T. Ró ż e wi c z opublikował w „Odrodzeniu” także pierwsze opowiadania, w których odwoływał się do przeżyć z okresu służby w partyzantce: Borem, lasem... (nr 43, z 23 IX) i Kiedy opadły liście (nr 56/57, z 23-30 XII); opowiadania te, przeredagowane (zwłaszcza pierwsze z nich, zatytułowane w nowej wersji Ciężar), wejdą potem do zbiorku Opadły liście z drzew (1955).

K. W. Za w od zi ń s ki, Rzut oka na literaturę polska 1945 roku. Poznań 1946, s. 28-29.

Tak opinię Zawodzińskiego traktuje Kła k (Spojrzenia, s. 88), który pomija jej kontekst i przywołuje jako przykład jaskrawego niezrozumienia przez krytyków oryginalności wierszy Różewicza.

T. Ró ż e wi c z: Na widnokręgu. „Odrodzenie” 1945, nr 42, z 16 IX; N 61. 
Ale warto pamiętać, że choć w swojej twórczości Różewicz szybko się od tego wpływu uwolnił, był w owym okresie szczerym admiratorem Przybosia i jako poety, i jako człowieka $^{44}$.

Mimo szybkiej ewolucji widocznej w wierszach Różewicza wpływ Przybosia w „zbiorowym” tomie opublikowanym w 1947 roku stanowił wątek bardzo wyraźny i odnotowywany przez wszystkich recenzentów. Także Zawieyski, który najwyżej oceniał „antypoetycki” sposób wyrażenia przez Różewicza „surowej prawdy” doświadczenia wojennego, dostrzegał, że „Niektóre wiersze dźwięczą Przybosiem w sposób bardzo niewątpliwy" 45 .

I tu ujawnia się inny jeszcze pożytek ze spojrzenia chronologicznego na zawartość Niepokoju. Można mianowicie zauważyć, że procesowi wypracowywania własnego idiomu poetyckiego odpowiadaja niejako symetrycznie zmiany wprowadzane potem przez Różewicza do tego tomu: „wczesne” wiersze, o ile w ogóle były przedrukowywane, poddane zostały radykalnym zabiegom redaktorskim, polegającym głównie na uproszczeniu języka, na rugowaniu metafor i epitetów, wiersze „późne” były częściej przedrukowywane i nierzadko bez żadnych zmian. Znamienne sa dalsze losy sześciu wierszy opublikowanych przez Różewicza jesienią 1945 w „Odrodzeniu”: wszystkie znalazły się w Niepokoju, ale tylko dwa z nich weszły następnie do Różewiczowskiego kanonu i były przez niego przedrukowywane - po większych lub mniejszych zmianach stylistycznych ${ }^{46}$. „Przepisywanie” Niepokoju rządzi się uchwytną reguła i ma walor pragmatyczny: prowadzi przede wszystkim do wyretuszowania i zmarginalizowania wpływów Przybosia. Jak to ujął Skrendo, „Różewicz nie tylko pomija wiersze zdradzajace genealogię Przybosiowską, niektóre także przerabia, aby pokrewieństwo takie zatrzeć" 47 .

Zawartość Niepokoju dokumentuje szybką ewolucję poezji Różewicza w latach 1945-1947. Jak już pisałem, ewolucja ta miała przebieg meandryczny, nie jest też jasne, w jakiej mierze była efektem przemyślanych decyzji, a w jakiej instynktownych poszukiwań; uderza w każdym razie, że przygotowując Niepokój poeta nie potrafił czy nie chciał dokonać wyboru spośród opublikowanych wcześniej wierszy, mimo że pozostawienie ich wszystkich oznaczało wprowadzenie do książ-

Podsumowujac pierwszy okres ich znajomości w liście napisanym w listopadzie 1947, po wyjeździe Przybosia na placówkę dyplomatyczną w Szwajcarii, Różewicz zaliczył się do jego „szkoły” i stwierdzał: „to było nie tylko terminowanie u Mistrza, [...] nie tylko była to szkoła rzemiosła, ale szkoła charakterów - sumienia - moralności” (cyt. za: Kłak, Spojrzenia, s. 39). Zob. też T. D r e w n o ws k i, Walka o oddech. Bio-poetyka. O pisarstwie Tadeusza Różewicza. Wyd. 2, uzup. Kraków 2002, s. $86-87$.

$45 \quad$ Zawieys ki, op. cit., s. 5.

46 Zabiegi redaktorskie Różewicza można obserwować na przykładzie utworu Ranny, którego przemiany zaprezentował Skrend o w Przepisywaniu Różewicza (s. 125-130) - jest to jeden z dwu przedrukowywanych spośród owych sześciu pierwszych wierszy; drugim jest Listopad 1944.

47 Skrendo, Przyboś i Różewicz, s. 149. Nb. trudno uzgodnić tę rzeczową konstatację ze sformułowaną później przez Skrendę (Przepisywanie Różewicza, s. 133) „symboliczną” interpretacją „przepisywania” Niepokoju. 
ki „krańcowych przeciwieństw”. Ten brak selekcji tym bardziej zastanawia, że Różewicz próbował jednak podporządkować zróżnicowany zbiór swoich wierszy ogólnemu zamysłowi - starał się skonstruować tom, którego dominantą miało być doświadczenie wojny, tom „postkatastroficzny” ${ }^{48}$. Na taki zamysł wskazuje wprowadzenie ramy kompozycyjnej: Niepokój otwierała Maska, jeden z najbardziej potem znanych wierszy Różewicza, wydrukowana w dodatku kursywą, co podkreślało jej wyjątkowość i nadrzędną rolę wobec innych utworów zbioru, zamykała zaś Gwiazda żywa, wiersz wchodzący w swoisty dialog z Maska, pokazujący, że ucieczka od pamięci o wojnie i od powojennej traumy, o której mowa w utworze inicjalnym słynne „uciekajmy uciekajmy” (N 3) - jest niemożliwa.

Drugi zasadniczy zabieg konstrukcyjny stanowiło w Niepokoju wymieszanie wierszy mniej lub bardziej bezpośrednio przywołujacych wojnę z tymi, w których takich przywołań brak. Przy „postkatastroficznej” koncepcji tomu był to zabieg konieczny, ponieważ wśród wierszy tworzących Niepokój te związane z doświadczeniem wojny bynajmniej ilościowo nie dominowały. Wydaje się, że intencje poety dobrze odczytywał Zawieyski, gdy stwierdzał:

Co chwila napotykamy w tomie rzeczy niewojenne, ale co chwila także wracamy na nowo do wojny. To zespolenie i przeplatanie odmiennej i różnorodnej wiedzy poetyckiej o świecie - potęguje wrażenie całości i nadaje jej akcent przejmującego tragizmu ${ }^{49}$.

Ale wymieszanie „rzeczy niewojennych” i „wojennych” odbierane być mogło i odbierane było, czego dowodzą inne recenzje - odmiennie: jako objaw niezdecydowania czy braku konsekwencji, poszukiwań chaotycznych na poziomie zarówno poetyki, jak i tematyki. Tym bardziej że w książce Różewicza pojawiły się zestawienia utworów, które mogły wręcz bulwersować, gdy np. po wierszu Matka powieszonych, w którym mowa, i to w jego zakończeniu, o obojętności innych (,idzie na dno / ociera się o szorstką łuskę tłumu”, N 9), autor umieścił estetyzujący obrazek jesieni - Bursztynowego ptaszka („Jesień / ptaszek bursztynowy / przejrzysty / z gałazki na gałązę / nosi kroplę złota”, N 10) ${ }^{50}$.

Muszę też podkreślić, że jeżeli pisałem o widocznej w Niepokoju ewolucji, to były to uwagi formułowane $\mathrm{z}$ perspektywy historycznoliterackiej, siłą rzeczy niedostępnej pierwszym czytelnikom książki Różewicza. W roku 1947 nie mieli oni podstaw, aby ujmować jej zawartość w porządkującej pespektywie ewolucji, skoro rezygnując $\mathrm{z}$ układu chronologicznego autor usunął tym samym zasadniczą wskazówkę pozwalającą uchwycić jej kierunek. Dlatego w utworach, w których dzisiaj skłonni jesteśmy widzieć krystalizowanie się idiomu „różewiczowskiego”, w 1947 roku dostrzegano przede wszystkim radykalną i chaotyczną zmianę literackich patronów,

To celne określenie J. Błońskiego stosuję tu anachronicznie, pojawiło się bowiem dopiero w jego recenzji Pięciu poematów („Pogłosy i zapowiedzi”. „Wieś” 1950, nr 25, z 25 VI), ale na znaczenie kompozycji Niepokoju zwracali już uwagę jego pierwsi czytelnicy - zob. S. Lichański, Dwa pokolenia awangardy. „Twórczość” 1948, z. 1, s. 93.

Zawi eys ki, op. cit., s. 5.

50 Wątpliwości związane $\mathrm{z}$ kompozycją nieobce były samemu Różewiczowi, który w następnych wydaniach Niepokoju zmienił ją, przesuwając wiersze „wojenne” zasadniczo do pierwszej części tomu, a Matkę powieszonych i Bursztynowego ptaszka rozdzielił wierszem Dola (poczynając od Wyboru wierszy z 1953 r.). 
to, że metaforyzowanie à la Przyboś młody autor zastępował, naśladując z kolei awangardowych poetów francuskich, „pewną manierą prozaizowania” 51 .

Różnorodność współtworzących Niepokój wierszy rodziła „trudność w rzetelnym i sprawiedliwym ocenianiu Różewicza"52. Henryk Vogler, dając bardzo zresztą przychylny opis tomu, tytułowy „niepokój” odnosił również do wyborów artystycznych poety (motyw ten powracał w innych recenzjach, być może pod wpływem Voglera - jego recenzja była chronologicznie pierwsza):

Poezja Różewicza jest nie tylko poezją niepokoju, ale także szukania. Wiele tu jeszcze elementów - przy rzadkiej ich piękności i odwadze poetyckiej - niezdecydowania, wiele rozmaitych źródeł inspiracji, które nieraz wydają się nawzajem wykluczać i wymagać będą w przyszłości, dla osiągnięcia ostatecznej dojrzałości, oczyszczenia i zdecydowanego wyboru ${ }^{53}$.

Jeszcze jedną opinię z 1947 roku warto tu przywołać, upublicznioną dopiero po kilkudziesięciu latach, ale znacząca, bo jej autorem był Kazimierz Wyka. W czerwcu tego roku pisał on w liście do Czesława Miłosza:

Ratuj, bo z poezją w tym kraju katastrofalnie źle. Jeżeli tomik robótek poetyckich Różewicza staje się wydarzeniem i ja nawet nie uniknę napisania o takowym, bo ustawiony w tle, ten tomik coś jednak mówi, zważ, jak wygląda tło ${ }^{54}$.

Nawet jeżeli wziąc poprawkę na stylistyczną nonszalancję, zrozumiałą w prywatnym liście, zaskakuje dziś i taka ocena Niepokoju, i lekceważący ton, w jakim została sformułowana, zaskakuje także ze względu na osobę autora: 10 lat później, po Październiku, Wyka stanie się ważnym promotorem twórczości Różewicza. W dodatku badacz był w swym sceptycyzmie wobec Niepokoju najwyraźniej szczery - i konsekwentny: recenzji tego tomu (ani Czerwonej rękawiczki) nie napisał. Nie wydaje się też kwestia przypadku, że w omówieniu książki poetyckiej Różewicza, które ostatecznie ukazało się w redagowanej wtedy przez Wykę „Twórczości”, motyw warsztatowych „robótek” był akcentowany - i krytykowany. Autor recenzji, Stefan Lichański, stwierdzał zdecydowanie, że w Niepokoju, podobnie jak w wierszach innych młodych poetów, „technicyzmu literackiego jest za wiele”, i przedstawiał ponura wizję upadku polskiej poezji, zbyt skoncentrowanej na problemach warsztatowych - „zabawa w układanie efektownych deseni ze słów trwa nadal i liryka polska stacza się coraz głębiej w formistyczne prestidigitatorstwo, coraz bardziej prymitywne i naiwne”. Różewicza, zdaniem Lichańskiego, pozytywnie wyróżniała spośród rówieśników powaga problematyki niektórych wierszy, ukazanie spowodowanego przez wojne „kryzysu moralnego”, ale ostateczna ocena tej poezji nie była jednoznaczna; podobnie jak w przypadku innych recenzentów, dystans Lichańskie-

Określenie B. O st r o m ę cki i go (Niepokój. „Nowiny Literackie” 1947, nr 29, z 5 X, s. 6); znamienne jest też zakończenie jego recenzji Niepokoju: „Zastanawiając się nad wierszami Różewicza dochodzimy do przekonania, że indywidualność autora toruje sobie drogę dopiero poprzez puszczę materiału poetyckiego, jakim dysponuje dorobek naszych czasów".

52 A. B ra u n, Zaczarowany flet. „Po Prostu” 1947, nr 6, z 20 X, s. 5. Recenzja ta ową trudność sama świetnie ilustruje, zawiera bowiem charakterystykę poezji Różewicza zdecydowanie odbiegającą od późniejszych sposobów jej ujmowania: dla Brauna autor Niepokoju to pełen melancholii „obserwator świata”, to „poeta pozbawiony pasji”, a „Ton uczuciowy jego wierszy jest raczej letni”. 
go budziła jej nieprzejrzysta wielokształtność: ,jest po prostu wyrazem wszechstronnych możliwości rozwojowych talentu, który jeszcze ze swej fazy mgławicowej nie wyszedl" 55 .

Niektóre sądy recenzentów Niepokoju czy opinia Wyki z 1947 roku mogą dziś zaskakiwać. Zapewne w jakimś stopniu dowodzą, jak chce Tadeusz Kłak, nieumiejętności dostrzeżenia oryginalności Różewicza. Ale też osobliwość tych opinii staje się mniej osobliwa, gdy rozpatrywać je w kontekście pierwotnej wersji Niepokoju. Była to książka poetycka naznaczona dwoma dążeniami. $Z$ jednej strony - do zapisania doświadczenia wojny i powojennej traumy. $Z$ drugiej - do zaspokojenia aspiracji literackich młodego autora. To drugie dążenie w wielu wierszach Niepokoju, nie tylko tych „najwcześniejszych”, wyraźnie dominuje i można podejrzewać, że stoi za nimi pragnienie, aby, jak to sarkastycznie, ale nie bez racji ujął Zawodziński, „zafundować sobie satysfakcję osiagnięcia celu: anch'io son' poeta!” Są w Niepokoju wiersze warsztatowe, ,robótki” w stanie czystym (Z notatek) czy obrazki poetyckie, których banalność miała zapewne równoważyć niezwykłość językowego ujęcia (Na widnokręgu, Zabawa ogrodowa, Wiatraczek, Droga na zachód, Słońce), jak i niemała grupa utworów, w których poeta starał się sprostać tematom w poezji „odwiecznym”: opisać wiosnę (Kwiecień, Deszcz wiosenny, Gotyk i wiosna), jesień (Bursztynowy ptaszek, Jesienny wiersz, Odlot) bądź relację miłosną między dwojgiem ludzi (Dłoniom poety, Stad, Kiedy odchodzisz, Uciszenie, Doskonata, Pożegnanie). Oczywiście, „Niepokój młodego poety jest nie tylko niespokojnym szukaniem nowego ornamentacyjnego efektu dla dawno już przezwyciężonych wzruszeń”, jak pisał Vogler ${ }^{56}$, choć takim szukaniem również bywał wcale nierzadko.

W pierwszej książce poetyckiej Różewicza uderza, że obok wierszy wyrażających „surowa prawdę” wydarzeń wojennych pojawiają się w znaczącej liczbie „poetyckie robótki". Ale dla dzisiejszego czytelnika zapewne bardziej nawet zaskakujące jest to, że uznana potem za charakterystyczną dla Różewicza sprozaizowana stylistyka Maski czy Ocalonego nie zawsze obowiązywała także wtedy, gdy autor podejmował temat wojny. I nie chodzi jedynie o formę przekazu poetyckiego, ale o mniej lub bardziej wyraźnie sugerowany sposób odbioru doświadczenia wojennego i jego interpretację. Podam tu trzy najwyrazistsze przykłady, cytując wiersze w całości, ponieważ, co zdecydowanie nieprzypadkowe, żaden $z$ nich nie wszedł do Różewiczowskiego kanonu.

W lutym 1946, zaledwie dwa miesiące przed opublikowaniem Ocalonego, Różewicz wydrukował w „Odrodzeniu” (1946, nr 7, z 17 II) wiersz Pacyfikacja, przywołujący dramatyczne wydarzenie: spalenie przez Niemców polskiej wsi, zapewne za pomaganie partyzantom (i w pierwodruku, i potem w Niepokoju wiersz ten jest poprzedzony utworem przedstawiającym postój partyzantów w zaprzyjaźnionej wiosce i zatytułowanym właśnie Postójj. 
Czub sosny zatoczył widnokrag muśnięciem lekkim jak wiatr, smugą czerwoną nad lasem i głową wschodził dzień.

Wartownik kudłaty w kożuchu kułakiem przecierał powieki, by widzieć $w$ głąb las,

szron zdmuchiwał $\mathrm{z}$ rzęs $\mathrm{z}$ drzew.

Pod górę na obłokach wspinał się samolot. Wyżej może stulił skrzydła i spadł w niebo, znikł. Na lotkach błysnął krzyż.

Zahuczał motor na trakcie, zahuczały motory dokoła, alarm, z gałęzi strącił lżejsze od echa białe płatki sniegu strzał.

Samolot wzbił niebo w górę, pikował w dół, salwą strzaskał gałęzie, drzewo rozpruł aż do rdzenia białej kości.

Minęło południe. Na śniegu długi modry cień. Schodził dzień. W podleśnej wsi piały o zachodzie czerwone koguty, a w lesie umierały różowe echa.

- ten młody (rozstrzelany w biegu, nim krzyknął) niesie na ustach gwiazdkę śniegu nie stopiona tchnieniem. [N 47-48]

Zmetaforyzowanie tego wiersza jest tak duże, że właściwie gdyby usunąc tytuł, można by mieć kłopot z precyzyjną odpowiedzią na pytanie, co tu jest przedmiotem opisu. To niewatpliwie efekt zafascynowania poezją Przybosia; fascynacji tej zresztą młody autor nie ukrywa, przeciwnie, sygnalizuje ją świadomym „przybosizmem”: „W głąb las”57.

Czytana po latach Pacyfikacja może zaskakiwać, i jako wiersz Różewicza, i ze względu na poetykę użytą do pisania o drastycznym wydarzeniu z czasów hitlerowskiej okupacji. Obie te kwestie ściśle się zresztą ze sobą wiążą, Pacyfikacja zaska-

O widocznym w Pacyfikacji silnym wpływie Przybosia pisał niedawno J. Łuka siewicz (TR. Kraków 2012, s. 30-31), dając szczegółową analizę tego wiersza. Do odnotowania jest jednak pewna osobliwość rozważań Łukasiewicza: Pacyfikację cytuje on za pierwodrukiem w „Odrodzeniu”, a wiersze z Niepokoju - z Utworów zebranych z 2005 r. i brak w jego rozważaniach informacji, że Pacyfikacja znalazła się w Niepokoju. Trudno powiedzieć, czy jest to efekt niedopatrzenia, czy też objaw uległości wobec Różewiczowskiego „przepisywania”. 
kuje, bo stoi na antypodach sprozaizowanej dykcji „Różewiczowskiej”, która, co jest miarą sukcesu autora Ocalonego, zyska potem powszechna aprobatę i zostanie uznana za niejako „naturalny” sposób ujmowania wydarzeń i doświadczeń wojennych. Warto więc przypomnieć, że metaforyzowanie w poezji polskiej tych wydarzeń i doświadczeń nie było i przed, i tuż po 1945 roku czymś wyjątkowym, wystarczy przywołać utwory Gajcego, Baczyńskiego - czy Przybosia. Poetyka autora tomu $W$ głab las (1932) nie uległa w latach 1939-1945 znaczacym przemianom, a jego młodzi wielbiciele naśladowali ją niezależnie od tematu ${ }^{58}$. Dla „czytelnika z 1947 roku" Pacyfikacja była zapewne utworem mniej niezwykłym, niż jest nim dla czytelnika dzisiejszego.

Natomiast z punktu widzenia ewolucji poezji Różewicza ważne jest to, że Pacyfikacji nie można potraktować jako przypadkowego efektu eksperymentów literackich młodego autora. Przeciwnie, wypada uznać, że Różewicz w roku 1945 czy na początku roku następnego wybierał taką poetykę świadomie, właśnie jako narzędzie mówienia o wojnie w poezji. Ważkim argumentem jest tu wiersz Śmierć podchorażego:

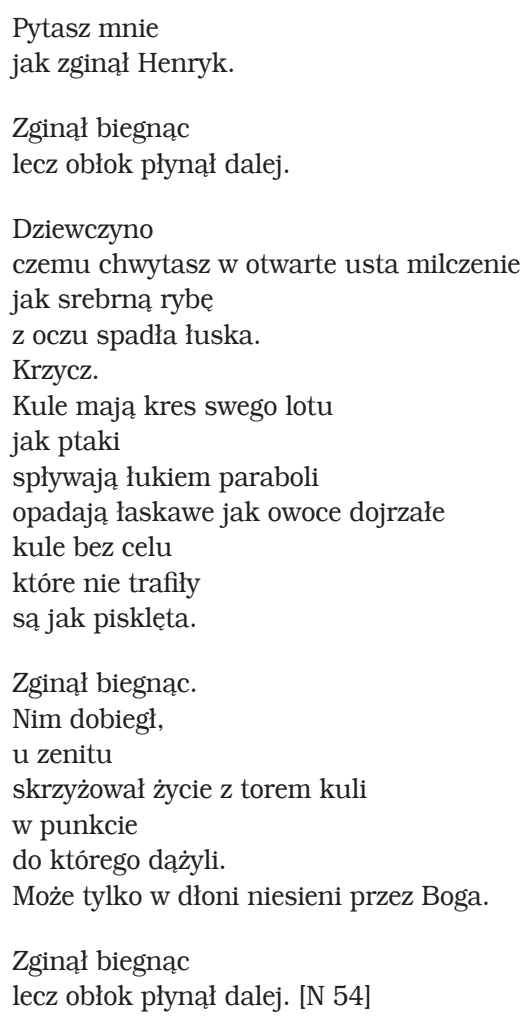

58 Np. J. La u opisał przybosiowskimi metaforami pierwszą publiczną egzekucję w Krakowie w $1943 \mathrm{r}$. (20 rozstrzelanym na Modrzejówce). Wiersze Laua opublikowane w tomiku U płomienia wiosną 1945 zapewniły mu tuż po zakończeniu wojny pozycję najwybitniejszego młodego naśladowcy Przybosia - zob. krótką recenzję-notę K. W y k i „U płomienia” („Odrodzenie” 1945, nr 31, z 1 VII). 
Punktem wyjścia jest w tym wierszu sytuacja dialogu. Dialog to jednak niezwykły, a suponowana konwersacyjność została wykorzystana do wprowadzenia kontrastu: na pytanie, które mogłoby być zadane w zwyczajnej rozmowie, pada odpowiedź niezwyczajna, podmiot mówiący okazuje się bowiem poetą. Buduje obraz, w którym konkrety zostały wyrażone tropami poetyckimi, w efekcie to, co mówi, odległe jest od codziennych użyć języka i potocznego ujmowania rzeczywistościs9.

Efekt kontrastu między zwykłością a poetycznością był zapewne jeszcze wyrazistszy w momencie ukazania się pierwodruku Śmierci podchorażego w maju 1946 („Odrodzenie” 1946, nr 21, z 26 V). Kontekst narzucał konkretyzację tego, co w tekście niedookreślone: tytułowa śmierć to zapewne śmierć w walce, w czasie niedawno zakończonej wojny. Co istotniejsze, moment historyczny wzmacniał szczególną „Zwyczajność" początkowego pytania: tego typu pytanie padało często, czego autor musiał być świadomy, w rozmowach potencjalnych czytelników jego wiersza, czyli tych, którzy - siłą rzeczy były to wiosną 1946 synonimy - zdołali przeżyć wojnę i okupację i którzy dowiadywali się teraz o wojennych kolejach losu, a zatem nierzadko o okolicznościach śmierci bliskich, przyjaciół, znajomych.

$Z$ tego też powodu manifestacyjnie poetycką odpowiedź na pytanie o okoliczności śmierci konkretnego człowieka - ową konkretność podkreśla wymienienie podchorazżego $z$ imienia - odczytać można jako świadomy gest metapoetycki, jako wyraz przekonania autora, że w taki sposób można i warto o dramatycznych wydarzeniach wojny pisać. A jednocześnie poetyckość ujawnia swoisty walor terapeutyczny: tropy poetyckie, eufemizując, pozbawiaja tytułową śmierć drastyczności i sugerują nieuchronność wydarzeń czy nawet ich zgodność z wyrokami Boskimi. Warto tu odnotować, że Śmierć podchorażego to wiersz autora Ocalonego także w dosłownym, chronologicznym rozumieniu tej peryfrazy: Ocalonego opublikował Różewicz w „Odrodzeniu” kilka tygodni wcześniej.

Jeszcze później niż Śmierć podchorażego, bo w końcu sierpnia 1946, ukazał się inny interesujący wiersz Różewicza: Walka ${ }^{60}$. W Niepokoju autor połączył oba wiersze w efektowny dyptyk, spoiwem jest pojawiający się w nich motyw biegu, który dodatkowo podkreśla związek bohatera Walki z zabitymi „towarzyszami broni”:

\author{
Biegnę, aby pojąć, \\ aby życie objąc oburącz \\ oto dojrzały moje dłonie \\ w świetle opadających lat \\ jeśli wyjdę $z$ ciemności \\ czy stanę się jako światło \\ może tylko będe lśnił \\ może tylko \\ za mną cień \\ nieodstępny towarzysz jasności
}

59 Bardziej szczegółową analizę wiersza Śmierć podchorażego daję w szkicu Tadeusz Różewicz pisze wiersze w 1946 roku, czyli poeta modernistyczny wobec wojny („Poznańskie Studia Polonistyczne” 2014, nr 24).

60 Ten wiersz, jako jedyny $z$ trzech tu omawianych, Różewicz jeszcze raz przedrukował: $\mathrm{w}$ Wyborze wierszy z 1953 r.; nie zmienia to jednak faktu, że jest to utwór zapomniany. 


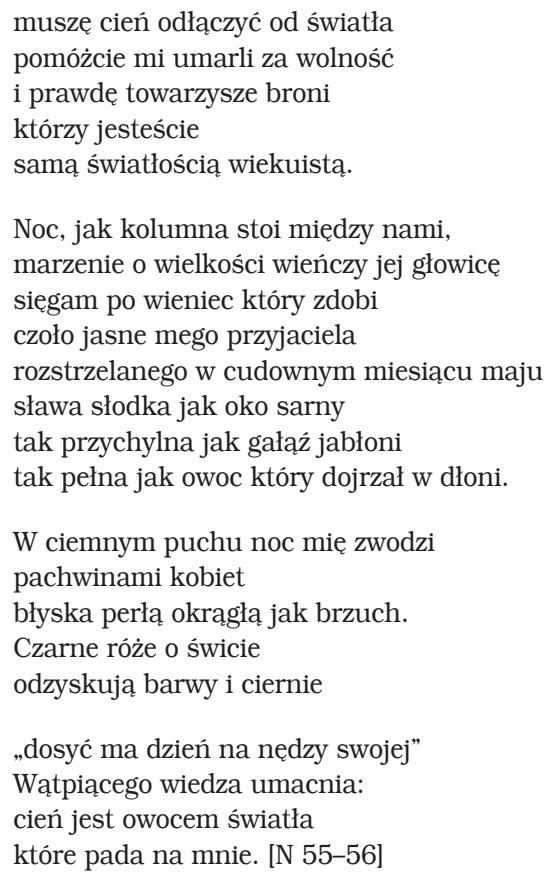

Walka jest wierszem pod wieloma względami zaskakującym. Zaskakuje już sfunkcjonalizowanie tytułu: pojawiające się w utworach Różewicza wcześniej (zarówno w porządku pierwodruków, jak w porządku Niepokojul przywołania wydarzeń wojennych, a także sąsiedztwo Śmierci podchorażego sugerowałyby znaczenie dosłowne określenia tytułowego, a tymczasem czytać je trzeba przenośnie, jako metaforyczny synonim życia; podobnie metaforyzuje się motyw biegu.

Walka zaskakuje zasadniczym konceptem: w całości oparta została na ogólnikowej, symbolicznej opozycji światła i cienia, podczas gdy już w okresie Niepokoju dla Różewicza charakterystyczne było skupianie się na konkrecie, nawet jeżeli metaforycznie opisanym (chociażby tak, jak to się dzieje w Pacyfikacji i w Śmierci podchorażego).

Zaskakuje w Walce patos, zwłaszcza w strofie piątej, a jeszcze bardziej sposób, w jaki Różewicz go uzyskał: poprzez odwołanie do tradycyjnej topiki i mało oryginalnej, wręcz anachronicznej stylistyki („sława” jako „wieniec który zdobi czoło”).

Zaskakuje cytat biblijny, pochodzacy z Ewangelii według św. Mateusza $(6,34)^{61}$ - to bodaj jedyny w powojennej poezji Różewicza ${ }^{62}$ przykład sięgnięcia do Bibliijako do autorytetu niekwestionowanego, w trybie czysto alegacyjnym (warto zauważyć,

Sformułowanie jest zresztą dość niezwykłe, na granicy zrozumiałości; przytaczam odnośny fragment w tłumaczeniu Biblii Tysiąclecia (Pismo Święte Starego i Nowego Testamentu. W przekładzie z języków oryginalnych. Oprac. Zespół Biblistów Polskich [...]. Wyd. 3, popr. Poznań 1990): „Starajcie się naprzód o królestwo Boga i o Jego sprawiedliwość, a wszystko będzie wam dodane. Nie troszczcie się więc zbytnio o jutro, bo jutrzejszy dzień sam o siebie troszczyć się będzie. Dosyć ma dzień swojej biedy".

W latach 1938-1939 młodziutki Różewicz opublikował kilka wierszy w piśmie Sodalicji Mariańskiej 
że także w Śmierci podchorażego przywołanie Boga czytać można nie tylko w kategoriach zwrotu retorycznego).

Ale przede wszystkim zaskakuje, zwłaszcza w kontekście utartych wyobrażeń o poezji Różewicza, aktywizm bohatera Walki. Wojna stanowiła dla niego doświadczenie dramatyczne, był on świadkiem śmierci „towarzyszy broni”; doświadczenie to jednak nie przerodziło się w zniewalającą traumę, przeciwnie, stało się swego rodzaju fundamentem poczucia obowiązku wobec tych, którzy wojny nie przeżyli, i motywowało do działania.

Niezwykłość Walki widać dobrze, gdy zestawi się ten utwór z arcyważnym później w recepcji poezji Różewicza Ocalonym, którego bohaterem jest człowiek straumatyzowany, dotknięty tak zasadniczą atrofią emocji i wartości, że zdaje się to uniemożliwiać jakąkolwiek aktywność, działanie, dążenie do celu. Są to utwory właściwie antytetyczne, ukazujące zdecydowanie odmienną reakcję na doświadczenie wojny, a ta odmienność uderza tym bardziej, że w obu pojawia sie podobna metaforyka: bohater Ocalonego szuka „nauczyciela i mistrza”, który „odzieli światło od ciemności”, bohater Walki traktuje to jako zadanie, z którym sam pragnie się zmierzyć: „muszę cień odłączyć od światła”, albowiem „wątpiącego wiedza umacnia”63.

Być może, osobliwość Walki w jakiejś mierze tłumaczą okoliczności towarzyszace publikacji tego utworu. Ukazał się on w pierwszym numerze „Pokolenia”, pisma, które miało być trybuną młodych ludzi o AK-owskiej przeszłości, aprobujacych jednak przemiany polityczne, jakie zaszły w Polsce wraz z końcem wojny. Niewykluczone, że Różewicz, który został oficjalnie krakowskim korespondentem tego pisma, próbował w swoim wierszu wyrazić postawę kręgu współpracowników „Pokolenia”, akcentując aktywizm ufundowany na poczuciu moralnego zobowiązania wobec tych, którzy zginęli, i możliwe, że z próbą wejścia w rolę trybuna pewnej zbiorowości wiązać trzeba zaskakująco anachroniczną stylistykę tego utworu.

Ale nawet jeśli tak było, pozostaje faktem, że Różewicz nie traktował Walki jako wiersza jedynie okolicznościowego, skoro zdecydował się przedrukować go w Niepokoju, efektownie łącząc ze Śmiercia podchorażego. Co więcej, niezależnie od swoich osobliwości, Walka wydaje się utworem bardzo ważnym w dorobku autora Niepokoju i wypada zgodzić się z Kłakiem, gdy stwierdza, że powinna powrócić do kanonu jego wierszy ${ }^{64}$ : Walka w sposób stosunkowo najbardziej otwarty wyraża i tłumaczy ówczesną postawę Różewicza, o wiele lepiej niż Ocalony czy inne najbardziej potem znane utwory $z$ lat 1945-1946. Była to postawa młodego człowieka z partyzancka przeszłością, który, mimo bagażu wojennych doświadczeń, zdaje maturę i podejmuje studia, a przede wszystkim aktywnie dąży do realizacji swojego marzenia o „sławie słodkiej jak oko sarny”, związanej z działalnością literacką:

„Pod Znakiem Maryi” - zob. T. Kła k, Liryka sodalisa. O juweniliach poetyckich Tadeusza Różewicza. W: Spojrzenia.

63 Jako przeciwstawienie Ocalonego zwykło się w różewiczologii czytać, z inspiracji Błońskiego, Gatazkę oliwną z Czerwonej rękawiczki (zob. S k r e n d o, Twórczość Tadeusza Różewicza w zarysie. W: Przodem Różewicz, s. 19), warto więc podkreślić, że takie przeciwstawienie, i to bardziej zasadnicze, fundujące „krańcowe przeciwieństwo”, pojawia się już w obrębie Niepokoju.

$64 \mathrm{~K} \nmid \mathrm{ak}$, Spojrzenia, s. 90. Autor zreszta na stwierdzeniu tym poprzestaje, zapomnianego utworu w żaden sposób nie prezentując i nie wyjaśniając, dlaczego miałby do Różewiczowskiego kanonu wrócić. 
poczatkujący poeta w okresie gimnazjalnym, jeszcze przedwojennym, następnie autor wydanych w konspiracji Ech leśnych, rozpoczyna już niejako oficjalną działalność literacką, wiele pisząc i publikując - obok utworów „poważnych” również satyryczne i humorystyczne (wierszem i proza), a także opowiadania oparte na przeżyciach $\mathrm{z}$ okresu okupacji.

Aktywizm bohatera Walki jest istotnym tropem autobiograficznym w Niepokoju - co każe $z$ dystansem spojrzeć na dominujące w różewiczologii przekonanie, że takim tropem jest skrajna trauma bohatera Ocalonego ${ }^{65}$. I to w świetle Walki zrozumiałe staje się - zaskakujące w kontekście Ocalonego - wspomnienie powojennej rzeczywistości, jakie autor Niepokoju zawarł w późnym wierszu Serce podchodzi do gardła:

\author{
w roku 1945 \\ w październiku \\ wyszedłem $z$ podziemia \\ zacząłem oddychać \\ słowo za słowem \\ odzyskiwałem mowę \\ zdawało mi się \\ że „Wszystko” układa się \\ dobrze \\ nie tylko w mojej głowie \\ ale na świecie \\ w domu w ojczyźnie \\ razem z Przybosiem szukałem \\ miejsca na ziemi \\ razem ze Staffem zacząłem \\ odbudowę od dymu \\ $z$ komina \\ razem $\mathrm{z}$ profesorem Kotarbińskim \\ głosowałem $3 \mathrm{x}$ tak 66
}

Traktowanie Ocalonego jako postaci wykreowanej przez Różewicza i od niego różnej nie jest zresztą ujęciem w różewiczologii zupełnie nie występującym, bywa niekiedy mniej lub bardziej otwarcie wypowiadane. Bodaj najwyraźniej starał się to zrobić A. Ściepuro w książce Kto jest poeta. Formy ,ja” lirycznego $w$ poezji Tadeusza Różewicza (Katowice 2001). Jednak, cenna ze względu na zasadniczy zamysł, książka Ściepury to jednocześnie szczególnie spektakularny przykład katastrofy, jaką pociaga za sobą zbytnie zaufanie do poety i nieuwzględnianie Różewiczowskiego „przepisywania”. Ściepuro cytuje wiersze Różewicza wyłącznie z wydania zbiorowego z r. 1988, co prowadzi do jaskrawych nieporozumień i wytwarza swoista fikcję zarówno na poziomie interpretacji (status fikcji przypisać trzeba ważnemu dla Ściepury, opatrzonemu rozbudowanym komentarzem, „faktowi”, że po Ocalonym pojawia się wiersz Nazywam milczeniem - w oryginalnym Niepokoju z 1947 r. po Ocalonym następowała Dola), jak i na elementarnym poziomie doboru uwzględnionych tekstów (Ściepuro nie przywołuje - i prawdopodobnie nie zna - Walki, innych wierszy usuniętych przez poetę z Niepokoju czy wielu jego utworów socrealistycznych, choć cała drugą część książki poświęca twórczości Różewicza z okresu panowania doktryny realizmu socjalistycznego).

T. Róż ewicz, Wyjście. Wrocław 2004, s. 27. 
Pacyfikacja, Śmierć podchorażego, Walka to wiersze skazane potem przez Różewicza na zapomnienie.

Przyczyniła się do tego zapewne ich wyrazista „poetyckość”, zdecydowanie różna od kształtującego się właśnie sprozaizowanego idiomu „Różewiczowskiego”. Mówiąc inaczej: trudno byłoby uznać, że wiersze te są dziełem „szarego człowieka z wyobraźnią / małą kamienną i nieubłaganą", by przywołać autocharakterystykę bohatera Wyobraźni kamiennej, traktowanego zazwyczaj jako porte parole autora ${ }^{67}$.

Ale ostatecznie, jak się wydaje, to nie „poetyckość” przesądziła o losie tych wierszy - kanoniczna potem wersja Niepokoju zawiera przecież trochę „poetyckich robótek". Ważniejsze okazało się zapewne to, że tropy poetyckie posłużyły do wyrażenia doświadczenia wojennego, które, jakkolwiek znaczące i dramatyczne, nie stało się obezwładniająca traumą - możliwy jest dystans estetyczny (Pacyfikacja), konsolacja (Śmierć podchorażego) czy deklaracja budowania własnego życia na wzór młodzieńczych wyobrażeń, których owo doświadczenie nie zdołało zmienić (Walka). $\mathrm{W}$ tych wierszach nie jawi się ono jako „nieubłagane”, nie determinuje w jednoznaczny sposób ani ich poetyki, ani postawy poety.

W słynnej frazie z Wyobraźni kamiennej, bardzo często przywoływanej w opisach wczesnej twórczości Różewicza, to właśnie epitet „nieubłagana” wydaje się kluczowy. Wyznacza punkt wyjścia, niejako inicjuje rozwijana potem przez autora Niepokoju narracje o wojnie jako zasadniczej cezurze w dziejach poezji. Groza doświadczeń wojennych wymusiła opowiedzenie się po stronie etyki i mówienia „wprost” - przeciw estetyce i poszukiwaniu efektownych metafor. Tak Różewicz przedstawiał to w połowie lat sześćdziesiątych w znanym eseju Do źródełt ${ }^{68}$. Równie znane jest pochodzace $z$ tej samej dekady posłowie do antologii wierszy Leopolda Staffa „Kto jest ten dziwny nieznajomy", zawierające m.in. często cytowany fragment ukazujący okoliczności powstania poezji „sprozaizowanej”:

Taniec poezji zakończył swój żywot w okresie drugiej wojny światowej w obozach koncentracyjnych, stworzonych przez systemy totalitarne. My wszyscy, którzy przeżyliśmy epokę czasów pogardy, razem z André Malraux zadaliśmy sobie to pytanie: „Czy na tej starej europejskiej ziemi człowiek umarł, czy nie?” Poezja Ruchu Oporu i poezja powojenna dała na to pytanie odpowiedź nie w języku Muz, lecz w języku ludzkim. Nawroty różnego rodzaju „tańców poetyckich” nie wytrzymały próby czasu. Słowo przestało się dziwić słowu. Metafora przestała rozkwitać69.

Wyraźna jest tu sugestia „nieubłaganej”, deterministycznej zależności: „graniczne" ${ }^{70}$ doświadczenie drugiej wojny światowej, nieuchronnie, i właściwie natychmiast, skoro odnosi się to także do „poezji Ruchu Oporu”, wymuszało radykalną przemianę poetyki. I choć Różewicz nie pisze tu o własnej twórczości, trudno przy-

Wyobraźnię kamienna Różewicz włączył do Czerwonej rękawiczki (1948), ale pierwodruk tego wiersza miał miejsce już w lutym 1947 („Odrodzenie” 1947, nr 6, z 9 II), jeszcze przed ukazaniem się Niepokoju - wraz z wierszem Szerokie czerwone usta, który w Niepokoju się znalazł. 
puścić, aby te konstatacje miały się do niej nie stosować. Przeciwnie, narracja o wojnie jako cezurze $\mathrm{w}$ dziejach poezji jest jednocześnie narracją budująca mit genezy poezji autora Niepokoju: doświadczenie wojny zdeterminowało powstanie „Różewiczowskiego” idiomu, w którym sprozaizowana dykcja służy ekspresji powojennej traumy psychicznie „okaleczonego” (jak sam siebie określa w Lamencie, N 8) bohatera tej twórczości.

Jest to jednak narracja tyleż na poziomie retoryki efektowna, co po prostu niejasna, kluczowe dla niej pojęcia są bowiem mgliste i niejednoznaczne ${ }^{71}$. Tak rzecz się ma np. z pojęciem języka ludzkiego, któremu trzeba przypisać równocześnie dwa różne znaczenia, do obu bowiem Różewicz się odwołuje. W odniesieniu do „poezji Ruchu Oporu” ów ,język ludzki” oznaczał zapewne, zgodnie z duchem polskiej frazeologii, mówienie „po ludzku”, w sposób zrozumiały dla odbiorców, co w praktyce dowartościowywało, i tak działo się w warunkach okupacji, twórczość literacką używająca ,języka Muz”, tyle że oswojonego przez konwencjonalizację, zgodnego z nawykami odbiorców i podporządkowanego wyrażaniu zbiorowych emocji ${ }^{72}$. Takim ,językiem ludzkim” posługiwał się sam Różewicz, gdy jako „Satyr” pisał utwory dla towarzyszy broni z partyzanckiego oddziału; znamienne, że ich zbiór zatytułował Echa leśne, podkreślając aluzją do Żeromskiego związek z polską tradycją literacką (i polską historia) ${ }^{73}$.

Co innego oznacza ,jezzyk ludzki” w odniesieniu do sprozaizowanej poezji powojennej: w tym wypadku chodzi o rezygnację z „tańca poetyckiego” metafor, stosowanie w utworach prostoty stylistycznej, potoczności, zwyczajności - tyle że sam zabieg wprowadzenia takiej stylistyki do polskiej poezji naruszał w drugiej połowie lat czterdziestych przyzwyczajenia odbiorców i utrwalone przekonania o „poetyckości” wiersza. Był to w swej istocie zabieg awangardowy i tak też odbierał go „czytelnik z 1947 roku”, co zgodnie potwierdzają recenzje pierwszych tomów poetyckich Różewicza ${ }^{74}$.

71 Zwracał na to uwagę A. S k r e n d o (Tadeusz Różewicz i granice literatury. Poetyka i etyka transgresji. Kraków 2002, s. 87, 97).

72 Tak rozumiany ,język ludzki” byłby bliski „folklorowi”, w znaczeniu, jakie nadał temu określeniu Balc erzan charakteryzując poezję okresu wojny - zob. cytowany tu wcześniej fragment Interpretacji jako „próby całości”; zob. też tego autora: Poezja polska w latach 1939-1965, s. 38-68.

73 Warto odnotować, że choć, jak sugeruje manifest Rekwizyty i duch, już w punkcie wyjścia twórczości powojennej Różewicz odcinał swoją (przyszłą) poezję od wpływu tak rozumianego ,języka ludzkiego", nie oznaczało to jednak jego potępienia. Przeciwnie, w r. 1946, w jedynej bodaj w swoim dorobku recenzji, już jako autor Ocalonego, bronił „poezji obowiązku” z czasów wojny, posługującej się sztafażem tradycyjnych środków literackich, aby oddać emocje zbiorowe, bronił, mimo że środki te zostały użyte niezbyt sprawnie. Zob. T. Ró ż ew i c z, Poezja obowiazku. „Odrodzenie” 1946, nr 28, z 14 VII. Recenzja dotyczyła tomu wierszy W. S z e w c zy k a Posagi (Katowice 1945), i wiersze te rzeczywiście wymagały obrony: patos zderzony z nieporadnością literacką dawał w utworach Szewczyka efekt niekiedy niezamierzenie groteskowy, np. gdy w utworze Generat Sikorski autor deklarował: „Generale, wiedziałeś, że jesteśmy wierni, / wszak nam nieraz gładziłeś lica w Oświęcimiu".

74 Jak pisał w omówieniu Niepokoju recenzent „Nowin Literackich”, O s tro m ę cki (op. cit., s. 6), „Niektóre "chwyty", cała atmosfera tej poezji obca jest właściwie czemuś, co w rozwoju naszej poetyki jest czymś organicznym, robi często wrażenie transplantacji dość mechanicznej, odnoszącej się raczej do zewnętrznego wyglądu wiersza. Widać tu zbliżenie do poezji francuskiej doby ostatniej $[\ldots] "$. 
Ale przede wszystkim stwierdzić trzeba, że narracji o wojnie jako cezurze w dziejach poezji nie da się uzgodnić z zawartością Niepokoju. Pokazuje ona w swojej różnorodności, że, parafrazując samego Różewicza, w 1945 roku metafora nie przestała rozkwitać, także w jego ówczesnych wierszach. Co istotniejsze, dowodzi, że nie istniała oczywista, „nieubłagana” reakcja poetycka na doświadczenie wojny, nie było narzucającego się związku między tym doświadczeniem a sposobem mówienia o nim w utworze poetyckim. Zawartość Niepokoju ujęta w porządku pierwodruków ujawnia, że sprozaizowany idiom pojawił się w wierszach Różewicza dopiero kilkanaście miesięcy po zakończeniu wojny, nie od razu też zaczął dominować. Niepokój nie jest efektem przejścia od „języka Muz” do „języka ludzkiego”, ale zbiorem utworów, w których obrębie przejście to dopiero się dokonuje.

\section{Abstract \\ PIOTR PIETRYCH Jan Kochanowski University, Kielce \\ “NIEPOKÓJ” (“ANXIETY”)-TADEUSZ RÓŻEWICZ'S 1947 ALMOST FORGOTTEN POETIC VOLUME}

Tadeusz Różewicz's 1947 Niepokój (Anxiety) is one of most crucial poetic volume in the history Polish $20^{\text {th }} \mathrm{c}$. literature and, as a matter of fact, most forgotten one. The article attempts to explain the origin of this paradoxical situation in which one should see both the consequences of the steps taken by Różewicz himself who markedly rephrased the volume, and a token of interpretive stereotypes durability that accumulated around Anxiety and that can be found even in the papers by such scholars (e.g. Tadeusz Kłak, Krzysztof Kłosiński) who declared the intention of critical evaluation of those stereotypes. Nonetheless, the article is also an attempt to reduce the literary historical carelessness: it aims to sketch the image of Anxiety's reception among its first readers, and above all it shows the diversified content of the 1947 volume which questions the fixed conviction about the straight and independent relationship between Różewicz's war experience and poetics of his early poems. 